\title{
Economics Analysis of Production, Resource Use Efficiency and Constraints Analysis of Sugarcane Cultivation in East Champaran District of North Bihar
}

\author{
Shiva Pujan Singh ${ }^{*}$, H.P. Singh ${ }^{2}$, Meera Kumari ${ }^{3}$, Md. Minnatullah ${ }^{4}$, \\ H. Chand ${ }^{1}$ and Balwant Kumar ${ }^{4}$
}

${ }^{1}$ Department of Agricultural Economics, Sugarcane Research Institute, Dr. Rajendra Prasad Central Agricultural University, Pusa, India

${ }^{2}$ Department of Agricultural Economics, BHU, Varanasi, India

${ }^{3}$ Department of Agricultural Economics, BAU, Sabour, Bhagalpur, India

${ }^{4}$ Sugarcane Research Institute, RPCAU, Pusa, India

*Corresponding author

\section{Keywords}

Sugarcane, Cost \& revenue, Input use efficiency and constraints analysis

Article Info

Accepted: 06 September 2018 Available Online: 10 October 2018

\section{A B S T R A C T}

The present paper estimate the cost and returns of sugarcane cultivation, input use efficiency and production constraints have been computed using primary data collected from 68 sugarcane growers on various aspects of costs and returns spread over two blocks in East-Champaran district of Bihar. The paper has analysed that an average sugarcane cultivating farmers in the area spent 33.71 percent of the total cost on hired labour, 21.72 percent on seed, 17.69 percent on chemical fertilizers, 11.98 percent on machine power and 4.26 percent on plant protection chemicals, realized a net return of Rs. 114183 per hectare. This might be due to the fact that the value of BCR has reached its maximum (2.74) only at the farm size of above two hectare. The study was shown that planting materials (seeds), tractor cost and plant protection chemical uses have a positive and significant influence on sugarcane yield, indicating that these resources are being used at sub-optimal levels and there exists the possibility of enhancing the yield of sugarcane by increasing their use. Labour shortage during peak period (81.50) average score in garret's ranking has been reported the major production constraints by the sugarcane growers. The general observation from the farmer's perception in the area is that in spite of the fact that the central and state Government price incentives have provided them a relief to some extent the mechanism evolved for fixing minimum price does not cover the entire cost components and the risk factors involved in the sugarcane cultivation.

\section{Introduction}

Sugarcane (Saccharium officinarum) is an important commercial crop of the world and is cultivated in more than 100 countries, the leading countries being Brazil, India, China,
Thailand and Pakistan. India is the largest consumer of sugar and second largest producer of sugarcane after Brazil. Its share in global sugarcane production was about 17 per cent in 2016-17. It is the second important commercial crop after cotton in India and 
grown in about 5.0 million hectares production of about 31 million tone contributing direct and indirect employment to 40 million farmers, 3.5 lakhs skilled and unskilled workers in the manufacturing of sugar.

Bihar is an important sugarcane growing state in the country with its area of 0.30 m.ha., ranks fourth in sugarcane area with a share of 5.58 percent. The average production of Bihar is $14.7 \mathrm{mt}$ (million tones) which is 4.68 percent of the total production of the country with yield level of 50tonesper hectare in 2016-17. In Bihar the major sugarcane growing districts are West-Champaran, East Champaran, Gopalganj, Sitamrhi, Siwan and Samastipur district respectively. Which do not only account for nearly 70 percent cane area but 60 percent of annual cane production of the state.

Sugarcane is an important commercial crop in the North Bihar. It has dominated the farming system in this region for a long time. Therefore, to explain the possibilities of raising farm production and farm income in this region. There are 28 sugar mills in Bihar, out of which 16 are sick and closed 12 are working in private sector.

The commercial farmer's chiefly concern is to secure a satisfactory margin between the cost and selling price of his produce. Thus in order to justify continuance a farm enterprise should generate a net profit over the total cost. Hence, this study becomes crucially important for the farmers to know their production cost. The cost of production and returns from sugarcane varies from region to region and from one category farmers to another.

The present study was carried out with the following specific objectives:

To find out cost and revenue gain in sugarcane cultivation.
To determine the resource use efficiency in sugarcane production.

To explore the constraints faced by Farmers in sugarcane cultivation and the suitable suggestion to overcome, these constraints.

\section{Materials and Methods}

East-Champaran district in Bihar was purposively selected for the study as this district has the second highest area after West Champaran district under sugarcane cultivation the state. Sugarcane in grown up as a major field crop by majority of the farmers in the district and had a maximum area of irrigated sugarcane cultivation.

The study is based on the primary data on various aspects were collected from the 68 sample farmers spread over in four village of two block from one leading district viz. EastChamparan with respect to sugarcane area, through pretested questionnaire by personal survey method with the help of multi stage random sampling technique. Post stratification was made to classify the farmers into three groups viz. marginal $(<1.0 \mathrm{ha})$ small $(1.0-2.0$ hac), and medium large ( $>2.0$ ha) categories based on their land holding.

\section{Analytical tools}

A part from budgeting technique and cost concepts, following analytical tools were employed (i) benefit cost ratio (ii) production function analysis and (iii) Garret's ranking technique for constraints analysis in sugarcane cultivation.

Production function analysis was used for determining the efficiency of various resources used in the process of production. The cobb-Douglas production function was used due to higher value of coefficient of multiple determinations obtained. 


\section{Production function}

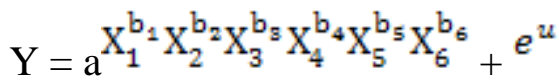

$\mathrm{b}_{1}=$ Regression coefficient

$\mathrm{u}_{\mathrm{i}}=$ Error term $(\mathrm{i}=1,2 \ldots . \mathrm{n})$

Where, $y$ is the yield of sugarcane (tons), $X_{i}$ is the human labour (manday), $\mathrm{X}_{2}, \mathrm{X}_{3}, \mathrm{X}_{4} \ldots \ldots \mathrm{X}_{6}$ denotes the cost of seed, manure and fertilizers, irrigation cost, tractor cost and plant protection chemicals respectively.

\section{Resource use efficiency}

The estimated coefficients of significant independent variables were used to compute the marginal value products (MVP).

$\mathrm{MVP}_{\mathrm{i}}=\mathrm{B}^{\frac{\bar{y}}{\bar{x}_{\mathrm{i}}} \times} \mathrm{P}_{\mathrm{y}}$

Here,

$\mathrm{MVP}_{\mathrm{i}}=$ Marginal value product of the $\mathrm{i}^{\text {th }}$ input

$\bar{y}=$ Geometric mean of the value of output (in rupees)

$\bar{x}_{n}=$ Geometric mean of the $\mathrm{i}^{\text {th }}$ input (value in rupees)

$\mathrm{B}_{\mathrm{i}}=$ Estimated co-efficient (or) production elasticity with respect to $\mathrm{x}_{\mathrm{i}}$ input.

$\mathrm{P}_{\mathrm{y}}=$ Price of out put

\section{Garrett's ranking technique}

The opinions survey of farmers sample about the various constraints in sugarcane production was collected and analyzed using Garrett's ranking technique. The ranks given by each respondent were converted into percent position by using formula.
Percent position $=\frac{100 \times\left(R_{i j}-0.5\right)}{N_{i}}$

Where,

$R_{i j}=$ Rank given to $\mathrm{i}^{\text {th }}$ constraints by the $\mathrm{j}^{\text {th }}$ individual and

$\mathrm{N}_{\mathrm{j}}=$ Number of constraints ranked by the $\mathrm{j}^{\text {th }}$ individual.

The estimated percent positions were converted into scores using Garrett's table. The mean score values estimated for each factor were arranged in the descending order. The constraints with the highest mean value was considered as the most important one and the others followed in that order.

\section{Results and Discussion}

Cost and return structure in sugarcane production

The cost of cultivation and cost of production of any crop is the most important aspects of the farm economy both at micro and macro level. The productivity level depends on the optimum allocation of resources which are always being considered either of scarce or costly and would have a definite impact on the cost and revenue structure of crop farms. It may be noticed that in agricultural production, cost of production refers to the expenditure incurred by the farmers on the various inputs (fixed and variable) to obtain the final produce. The fixed cost includes depreciation, taxes, rent, interest, etc, which results from past commitments of costs already sunk. It is constant over time and does not change with the changes in crop output. On the other hand, there are variable cost viz. cost of human labour (family and hired), machinery power, seeds, manures, fertilizers, plant protection chemicals, etc. which are directly linked up with output. This would be an important cost 
which determine how much and what is to be produced. Therefore, it is the variable cost, based on which the major cropping decisions are taken at farm levels. The estimated cost and revenue particulars of sugarcane production pertaining to the different farm level data collected from the sample farmers of four villages of two blocks of East Champaran district is furnished from Table 1.

A perusal of table 1 reveals that an average sugarcane cultivation, farmers in the area spent 33.71 percent of the total operating cost, on hired human labour, 1.08 percent on bullock power, 11.98 per cent on machinery used for different operations. Out of total operational cost, shared of material cost seed (setts), fertilizer, plant protection chemicals and irrigation charges was 21.79 percent, 17.69 percent, 4.26 percent and 6.47 percent respectively. In other words of the cost constituents, the share of hired labour was recorded to be the maximum, indicating the fact that sugarcane production in the area is largely depend upon hired labour.

Human labour utilization was maximum in planting; inter cultivation, followed by harvesting and transportation cost of seed occupied the second important position in the cost of cultivation of sugarcane, as it is the basic input on which the inters production depend. Among the various categories of farms through the average trends in the use of factor inputs continue in all categories of farms, there had been a significant difference observed between farms, especially in the use of machine power. From the point of view of net return, this tended to increase with farm size. This might be due to the fact that the benefit of economics of scale has reached its maximum only at the farm size of above 2.0 hectors). The crop productivity was $90 \mathrm{t} / \mathrm{ha}$ under medium and large size farm and 53 t/ha in marginal farm condition. So, there was 70 per cent higher yield.

\section{Resource use efficiency}

For sugarcane growers of East-Champaran:-

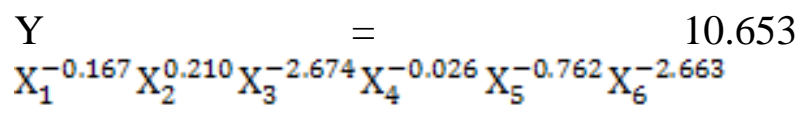

The Cobb-Douglas type of production function was fitted for the estimation of elasticities of important variables contributing to the yield of sugarcane crop. It is very important because resources of the farmers are limited (Table 2). The value of co-efficient of multiple determinations $\left(\mathrm{R}^{2}\right)$ was found to be more than 0.961 in farms indicating that the explanatory variable included in the model can explain more than96 per cent variation in yield of sugarcane crop. The human labour utilized in sugarcane cultivation was negative and nonsignificant in some cases may be due to timely, unavailability of human labour. The utilization of seed, tractor cost and plant protection chemical was significant with positive sign for all the farm size. The significant and positive co-efficient indicates that there is scope for increasing, seed and plant protection chemicals for enhancing sugarcane productivity. The manure and fertilizers utilize in sugarcane crop enhancing efficiency, these inputs co-efficient were negative and non-significant. It was reported during field investigation that most of the sample, farmers used excess quantity of manures and fertilizer than the recommended level. Return to seale (sum of the production elasticity) was found (0.768) exhibit increasing return to scale indicates that simultaneous increase of one percent in factor of production yield, increase more than are percent in gross return.

\section{Comparison of marginal value product (MVP) with acquisition cost}

The marginal value product of all the resources were compared with their 
corresponding acquisition cost i.e. the cost price plus interest and the differences between the two were tested statistically for their significant with the help of t-test.

The perusal of the Table 3 indicates that the marginal value product of seed, plant protection chemicals and tractor cost is significantly higher than its acquisition cost, it indicates indicating that there is sub-optional use of the seed, irrigation and tractor cost. Therefore is need to increase the level of seed, irrigation and tractor cost to achieve maximum return. The marginal value productivity of manure and fertilizers is significantly lower than the requisition cost, indicating that there is excess use of these resources than the recommended level, there is need to decrease use of manure and fertilizers application to achieve maximum return. The interpretation of marginal value product has been made with respect to those resources only whose regression coefficients were found to be significant.

Table.1 Estimated cost and revenue particulars of sugarcane cultivation in East Champaran district

\begin{tabular}{|c|c|c|c|c|}
\hline \multirow[t]{2}{*}{ Cost/revenue particulars } & \multicolumn{4}{|c|}{ Farm size in ha. } \\
\hline & $<1.0$ & $1.0-2.0$ & $>2.0$ & All \\
\hline Cost of Family labour & $\begin{array}{c}69.01 \\
(11.52)\end{array}$ & $\begin{array}{c}3204 \\
(4.79)\end{array}$ & $\begin{array}{c}2184 \\
(2.50)\end{array}$ & $\begin{array}{c}3165 \\
(4.15)\end{array}$ \\
\hline \multirow[t]{2}{*}{ Cost of hired labour } & 18291 & 24895 & 28153 & 25684 \\
\hline & $(30.54)$ & $(37.20)$ & $(32.30)$ & $(33.71)$ \\
\hline \multirow[t]{2}{*}{ Cost of machine power } & 5514 & 6787 & 11774 & 9126 \\
\hline & $(9.20)$ & (10.14) & $(13.51)$ & (11.98) \\
\hline \multirow[t]{2}{*}{ Cost of seed (setts) planting } & 14543 & 15215 & 18043 & 16548 \\
\hline & $(24.29)$ & $(22.73)$ & $(20.70)$ & $(21.72)$ \\
\hline \multirow{2}{*}{ Cost of chemical fertilizer } & 7830 & 9466 & 17875 & 13476 \\
\hline & (13.07) & (14.04) & $(20.50)$ & $(17.69)$ \\
\hline \multirow[t]{2}{*}{ Cost of plant protection chemicals } & 2253 & 2707 & 3899 & 3246 \\
\hline & $(3.76)$ & $(4.04)$ & $(4.47)$ & $(4.26)$ \\
\hline \multirow[t]{2}{*}{ Cost of irrigation charges } & 4546 & 4654 & 5244 & 4936 \\
\hline & $(7.59)$ & $(6.95)$ & $(6.01)$ & $(6.47)$ \\
\hline \multirow[t]{2}{*}{ TVC } & 59878 & 66928 & 87172 & 76181 \\
\hline & $(100)$ & $(100)$ & $(100)$ & $(100)$ \\
\hline DIRTI-5 & 6469 & 7928 & 21818 & 14712 \\
\hline TC & 66347 & 74856 & 108990 & 90893 \\
\hline TR & 152468 & 177929 & 238522 & 205076 \\
\hline Net revenue (TR-TC) & 86121 & 103073 & 129532 & 114183 \\
\hline Revenue over total variable cost (TR-TVC) & 92.590 & 111001 & 151350 & 128895 \\
\hline B:C ratio (on variable cost) & 2.55 & 2.66 & 2.74 & 2.69 \\
\hline $\mathrm{B}: \mathrm{C}$ ratio (on total cost) & 2.30 & 2.38 & 2.18 & 2.26 \\
\hline Yield (t/ha) & 53 & 71 & 90 & 78 \\
\hline Cost of production (Rs./t) & 1252 & 1054 & 1211 & 1165 \\
\hline
\end{tabular}

Source: Survey data (figures in parentheses indicate percentage) 
Table.2 Cobb-Douglas production function estimates for sugarcane crop

\begin{tabular}{|c|l|c|c|c|}
\hline SI No. & \multicolumn{1}{|c|}{ Particulars } & $\begin{array}{c}\text { Regression } \\
\text { coefficient }\end{array}$ & Standard error & t-value \\
\hline $\mathbf{1}$ & Intercept(A) & 10.653 & 2.111 & 5.045 \\
\hline $\mathbf{2}$ & Human labour (Mandays) $\mathrm{X}_{1}$ & -0.167 & 0.202 & -0.828 \\
\hline $\mathbf{3}$ & Seed (Rs.) $\mathrm{X}_{2}$ & $0.210^{* *}$ & 0.080 & 2.626 \\
\hline $\mathbf{4}$ & Manure and fertilizer (Rs.) $\mathrm{X}_{3}$ & -2.674 & 0.782 & -3.419 \\
\hline $\mathbf{5}$ & Irrigation cost (Rs.) $\mathrm{X}_{4}$ & -0.026 & 0.125 & -0.210 \\
\hline $\mathbf{6}$ & Tractor Cost (Rs.) $\mathrm{X}_{5}$ & $0.762^{* * *}$ & 0.382 & 1.995 \\
\hline $\mathbf{7}$ & Plant protection chemicals $\mathrm{X}_{6}$ & $2.663^{* *}$ & 0.677 & 3.932 \\
\hline $\mathbf{8}$ & Sum of elasticities $\left(\sum b_{i}\right)$ & 0.768 & - & - \\
\hline $\mathbf{9}$ & Co-efficient of multiple determination $\left(\mathrm{R}^{2}\right)$ & 09.61 & - & - \\
\hline
\end{tabular}

Note: $* * *$ and $* *$ indicate significant at $1 \%$ and5\% probability level respectively

Table.3 Comparison of marginal value product (MVP) of the resources with their acquisition cost in East Champaran district

\begin{tabular}{|c|c|c|c|c|c|c|}
\hline \multirow[t]{2}{*}{ Crop } & \multicolumn{6}{|c|}{ Resources } \\
\hline & $\begin{array}{c}\text { Human } \\
\text { labour } \\
\left(\mathbf{X}_{1}\right)\end{array}$ & $\begin{array}{l}\text { Seed } \\
\left(\mathbf{X}_{2}\right)\end{array}$ & $\begin{array}{c}\text { Manure \& } \\
\text { fertilizer } \\
\left(\mathbf{X}_{3}\right)\end{array}$ & $\begin{array}{c}\text { Irrigation } \\
\operatorname{cost}\left(\mathbf{X}_{4}\right)\end{array}$ & $\begin{array}{l}\text { Tractor } \\
\operatorname{cost}\left(\mathbf{X}_{5}\right)\end{array}$ & $\begin{array}{c}\text { Plant } \\
\text { chemicals } \\
\left(\mathrm{X}_{6}\right)\end{array}$ \\
\hline $\begin{array}{l}\text { MVP at Geometric } \\
\text { mean }\end{array}$ & -1.16 & $3.26 * * *$ & -23.45 & -0.96 & $19.51 * *$ & $17.52 * * *$ \\
\hline $\begin{array}{l}\text { Acquisition cost } \\
\text { (per unit price) }\end{array}$ & 1.12 & 1.12 & 1.12 & 1.12 & 1.12 & 1.12 \\
\hline Differences & -2.28 & 2.08 & -24.57 & -2.08 & 18.39 & 16.40 \\
\hline Standard error & 0.202 & 0.080 & 0.782 & 0.125 & 0.382 & 0.677 \\
\hline
\end{tabular}

Note: $* * *$ and $* *$ indicate significant at $1 \%$ and $5 \%$ respectively

Table.4 Production constraints of sugarcane in East Champaran district $(\mathrm{N}=68)$

\begin{tabular}{|c|l|c|c|}
\hline SI. No. & \multicolumn{1}{|c|}{ Particulars } & $\begin{array}{c}\text { Mean } \\
\text { scores }\end{array}$ & Garret ranking \\
\hline $\mathbf{1}$ & Labour shortage during peak period & 76.97 & IV \\
\hline $\mathbf{2}$ & Poor source of irrigation & 81.50 & I \\
\hline $\mathbf{3}$ & Non-availability of fertilizer on time & 77.03 & III \\
\hline $\mathbf{4}$ & Non-availability of improved variety of seed & 76.78 & V \\
\hline $\mathbf{5}$ & High cost of plant protection chemicals & 75.22 & VI \\
\hline $\mathbf{6}$ & Expensive improved technology & 76.03 & VII \\
\hline $\mathbf{7}$ & Low selling price of the produce & 71.11 & IX \\
\hline $\mathbf{8}$ & Lack of knowledge of scientific crop production & 81.04 & II \\
\hline $\mathbf{9}$ & Pests and disease attack & 72.93 & VIII \\
\hline $\mathbf{1 0}$ & Unavailability of loan on time & 71.00 & X \\
\hline
\end{tabular}


Constraints faced by cultivators in production of sugacane

The constraints being faced by the sample, sugarcane growers were ranked using Garrett's ranking technique and the results are given in Table 4.

The major constraints were labour shortage during peak period as higher wages and most of the laboures work under MNREGA scheme. The second most significant constraints was non availability of chemical fertilizer on time with (81.04) average score in Garrett's ranking, identified. The other constraints were non-availability of planting material poor source of irrigation and high cost of plant protection chemicals and fertilizers.

\section{Summary and policy implications}

As a result, the estimates of the economics of sugarcane production in East Champaran district, the following observations can be accounted for policy planning suitable to this region.

It is worth pointing that the expenditure on hired human labour was recorded to be the highest among all operating costs for sugarcane cultivation in the area.

Seed planting/seed cost, being a basic input recorded to be an average of about 21.72 per cent for sugarcane.

The net return per hectare and $\mathrm{B}-\mathrm{C}$ ratio on operating cost was found highest Rs. 129532 for larger farms respectively.

The study has shown that inputs such as planting materials (seed sett), irrigation and plant protection chemicals have positive and significant influence on the yield of sugarcane crop. The poor source of irrigation and labour shortage in pick season and non-availability of chemical fertilizer on time was found significant constraints/problem in this region.

Hence, farmers need timely supply of quality seed and other inputs (Irrigation, fertilizer, pesticides etc.) and remunerative prices for their produced.

The study recommends that can improve the cropping system and stabilizes farm income to the farmers with the increase in the extent of irrigation facilities. For water scarcity use of drip irrigation and precision farming may be popularized.

The problem of non-availability of labour may be addressed by using low cost machineries and implements.

The paper has suggested that to enhance the production and productivity farmers should be motivated through visit to progressive farmers field and organizations of field demonstration and other communication means to use the recommended level of inputs and improved variety of seeds to enhanced the productivity of sugarcane in the state.

\section{References}

Ahmed, P., R.K. Nath and A.C. Sarmah (2016) production constraints of sugarcane cultivation in Tinsukia District of Assam. International Journal of agriculture Sciences. ISSN 09759107, Volume-8 Issue 62, PP-35403541.

Goddi, G.M., Mundinamani and Patil, S.A (2002). Yield gaps, constraints and potential in cotton production in North Karnataka-An econometric Analysis. India Jr. of Agricultural Economics Vol. 57, No. 4 PP - 722-754. 
Karthick, V. Alagumani, T. and Amarnath, J.S. (2013). Resource use efficiency and technical efficiency of turmeric production in Tamil Nadu-A stochastic frontier approach. Agricultural Economics Research Review 26(1): 109-114.

Rama Rao, I.V.Y., (2012). Efficiency, yield gap and constraints analysis is irrigated vis-à-vis rainfed sugarcane in north coastal zone of Andhra Pradesh. Agricultural Economics Research Review 25(1):167-171.

Saravanan, A (2016). Analysis of cost and returns of sugarcane production is Erode district of Tamil Nadu. Indian Journal of Economics and Development 4(8): 1-4.

Saravanan, K., S., Parvati (2015). An Analysis of cost and returns of sugarcane production in Krishnagiri District of Tamil Nadu. International Journal of Research 2(2): 378-384.

Singh, Shiva Pujan, Singh, H.P, Meera Kumari and Meena Lokesh, (2018). Assessment of variation in yield gap and constraints analysis in sugarcane production in Bihar International Journal of current Microbiology App. Sciences special Issue-7:2667-2675.

Tripathi, R.S., Raju, R and Thimmappa, K., (2013). Impact of zero tillage on economics of wheat production in Haryana.

Verma, A.R. (2005). Economic analysis of production and resource use efficiency of potato in Indore district of Madhya Pradesh. Indian Journal of Agricultural Economics vol. 60. No. 3, July-Sept. P. 515.

\section{How to cite this article:}

Shiva Pujan Singh, H.P. Singh, Meera Kumari, Md. Minnatullah, H. Chand and Balwant Kumar. 2018. Economics Analysis of Production, Resource Use Efficiency and Constraints Analysis of Sugarcane Cultivation in East Champaran District of North Bihar. Int.J.Curr.Microbiol.App.Sci. 7(10): 512-519. doi: https://doi.org/10.20546/ijcmas.2018.710.056 